Like the two wary cultural giants they were, Whitman and Roosevelt each grudgingly admired the other, knowing they each would have said and done things differently but knowing too that they shared key values. Whitman even anticipated one of Rossevelt's signature expressions, when he wrote in the poem that he would eventually entitle "Crossing Brooklyn Ferry": "Bully for you! you proud, friendly, free Manhattanese!" Whitman had recorded the phrase in his early notebooks as one of the colorful expressions he heard among New York workers and Bowery boys, and it stayed in his poem until the 1870 edition of Leaves of Grass, when he omitted it. ${ }^{3} \mathrm{He}$ once toyed with the idea of writing a "poem of a proud, daring, joyous expression-for Manhattan island!," and calling it "Bully for you, Manhattan!"4 That's a manuscript we can imagine Roosevelt really would have desired, but the Whitman manuscript that he did own, with its demand for "something rough" in America and its disdain for "thin-blooded rose-scented gentlemen, dandies," would of course have appealed to the Rough Rider, even if he was never aware of Whitman's characterization of him as just a little too much the "dude."

Brooklyn, New York

Sherry Ceniza

The University of Iowa

Ed Folsom

Texas Tech University

Jerome Stueart

\title{
NOTES
}

1 Clara Barrus, Whitman and Burroughs: Comrades (Boston: Houghton Mifflin, 1931), 364.

2 Horace Traubel, With Walt Whitman in Camden (New York: D. Appleton and Company, 1908), 2:411.

3 Whitman records the phrase in $D B N, 669$. Whitman occasionally used the term himself, as in a November 1863 letter to Thomas P. Sawyer: "The elections went bully" (Corr., 1:186).

4 NUPM, 1327. William Sloane Kennedy in 1926 commented on Whitman's "Bully for you!" line: "I am sorry to say that our then immature poet exclaimed, á la Roosevelt:-'Bully for you!'” Kennedy, The Fight of a Book for the World (West Yarmouth, MA: Stonecroft Press, 1926), 167.

\section{WALT WHITMAN'S ADVICE TO NEW JERSEY STATE SCHOLARS: AN UNKNOWN INTERVIEW}

In February 1888, The Signal, the student newspaper of The College of New Jersey (then the New Jersey State Normal and Model Schools), published an interview with Walt Whitman titled "Walt Whitman's Advice to the State Scholars." The Signal came into existence in 1885, and two of its pioneers-George Worman, class of 1886, and Francis B. Lee, class of 1888-had traveled to Camden to conduct the interview with Whitman, soliciting advice for those state scholars who wished to follow the "literary life." The interview, the first 
one conducted by The Signal, presents Whitman's strong pedagogical nature, as he gladly offers literary advice to the young state scholars. Here is the text in its entirety:

\section{Walt Whitman's Advice to the State Scholars}

In a little house, narrow and low, facing Mickle Street, in the city of Camden, N.J., there lives to-day a man who, in his own way, following the dictates of his own peculiar conscience, he himself pervaded with that poetic "ego" which has marked toward infinity the limit of his intellect, has done more to revolutionize poetic thought than any other writer of the nineteenth century. That man is Walt Whitman, the gray-haired, handsome, aged poet of Camden, who to-day has won for himself a world-wide reputation as a leader among men.

With George Worman, Model Class of '86, I called upon Walt Whitman some time ago and asked him if he could give to us some rule or regulation whereby those in the State Schools of New Jersey, who desired to follow a literary life, could profit, and better equip themselves for the fray.

The poet sat in a great oak chair by the fire; the room was cheerful in the morning sunlight, which streamed upon a carpet of waste paper-letters, journals, pamphlets, story books and manuscript. The somewhat impudent character of the question propounded by partial strangers, if I may use the term, (I had met Walt Whitman a year or so before this interview,) seemed to please the poet, for he laughed and said: "Yes, I'll tell you what to say to the State scholars who have literary ambitions. Just this: Practice is the main thing at all times, and subservient to this but almost equal in importance, is the statement never be discouraged. Whack away at everything pertaining to literary life-mechanical part as well as the rest. Learn to set type, learn to work at the 'case', learn to be a practical printer, and whatever you do learn condensation. I'll tell you the best literary characters are individualistic; they let out what they have in them; they give themselves full sweep and play. This is true, especially in America, where thought is untrammeled and men are free. To young literateurs I want to give three bits of advice: First, don't write poetry; second ditto; third ditto. You may be surprised to hear me say so, but there is no particular need of poetic expression. We are utilitarian, and the current cannot be stopped. To people who will write verse, I have nothing to say. This much I will state, that at present it is a great struggle to get out of the mud into which conventional poetry has placed us. The efforts of the poets of the past is to put us in the mire. We must not be conventional, we must be free.

"I make another suggestion. It is a good plan for every young man or woman having literary aspirations to carry a pencil and a piece of paper and constantly jot down striking events in daily life. They thus acquire a vast fund of information. One of the best things you know is habit. Again, the best of reading is not so much in the information it conveys as the thoughts it suggests. Remember this above all. There is no royal road to learning."

So ended our interview with one of the strangest, one of the sublimest poets America ever produced: with Whitman, a poet who told us he acquired meter as the eye sees or the bird sings: with a person who knows the world-to whom a man is the true image of the Maker, and who to-day has scarcely an equal in this or any other land.

CESSATOR. ${ }^{1}$

The interview presents Whitman's authoritative voice advising amidst his notorious disarray of papers. He employs a favorite phrase- "Whack away"- 
uttered numerous times in Horace Traubel's With Walt Whitman in Camden, as when Traubel asks Whitman whether he will finish reading The Life of Samuel fohnson: "Oh yes! I'll whack away at it. I don't care much for it, but I will finish it as duty." 2

The familiar voice also speaks on familiar topics, especially the notion that there is "no royal road to learning." Whitman was a lifetime supporter of educational reform, backing advocates for change like Horace Mann, detesting the cruelties of the Lancastrian system, and opting for change by drawing his students out "through provocative questions." 3 Whitman often sounded his disgust with conventional scholars, reporting his "lack of interest in Harvard" and his disdain for the "supercilious, overbearing" New England men. ${ }^{4}$ One subject about which Whitman did not contradict himself was his consistent belief that the scholar should learn by encountering life instead of reading books alone. The teacher-pupil relationship is one that was essential to Whitman the man and Whitman the poet, and the advice he offers in the interview to "practice" and "jot down striking events in daily life" is consistent with his advice in "To A Pupil": "Rest not till you rivet and publish yourself of your own Personality." 5

The most striking aspect of the interview is Whitman's seething rejection of poetry. He tells the two students: "First, don't write poetry; second ditto; third ditto. . . . To people who will write verse, I have nothing to say." Whitman's aversion to conventional, "royal" forms of education makes his disdainful remarks against poetry really not as "surprising" as Whitman thinks his interviewers will find them; his rejection of poetry is simply part of his attack on conventionality in all respects. In this interview, he chooses to target poetry as his example of conventionality by saying that "at present it is a great struggle to get out of the mud into which conventional poetry has placed us." The point of reading, Whitman adds, "is not so much in the information it conveys as the thoughts it suggests," and so reading poetry, a form historically bound by tradition, only reinforces conventional thinking. Additionally, poetry can never be "utilitarian"-in no way can it reach the masses for their benefit - and so Whitman becomes rather pessimistic about the prospect of poetry in the United States. In "A Backward Glance," written earlier that year, he had lamented the fate of Leaves of Grass: "That from a worldly and business point of view 'Leaves of Grass' has been worse than a failure-that public criticism of the book and myself as author of it yet shows mark'd anger and contempt more than anything else." ${ }^{16}$ Poetry, then, by continually slipping back into its conventional habits, fails Whitman's expectations, for what America needs is freedom, not rule-bound, processional tradition: "We must not be conventional, we must be free."

It is also no surprise, therefore, that Whitman consented to an interview conducted by two student journalists from the New Jersey State Normal School, a school founded to break from the traditional, "royal road" to learning. The New Jersey State Normal School, now The College of New Jersey, was founded in 1855 by William F. Phelps. Phelps, like Whitman, held fast to the educational reformist ideas introduced by Horace Mann, as he implemented New Jersey's first teacher's college in response to the growing need for state teachers. ${ }^{7}$ The Normal School shared space with the state Model School, a second- 
ary school and junior college, which became "one of the outstanding. . . schools in the state, with many distinguished graduates." 8 The Normal and Model Schools attracted the best of the state, including the two Whitman interviewers, who after creating the Normal/Model Schools' newspaper, The Signal, in 1885 (which still exists as The College of New Jersey's student paper today), traveled to Camden three years later to solicit the Good Gray Poet's advice.

George Worman, the interviewer mentioned within the article, most likely arranged the interview. From the time of his Model School graduation in June 1886, Worman wrote for the Coast Pilot and the Camden Courier, two newspapers based in the Camden area..$^{9}$ Whitman, during his time in Camden, was a contributor to the Camden Daily Post, which eventually merged with the Courier and the Camden Daily Telegram to become what is now the Courier-Post. ${ }^{10}$ This merger highlights the two papers' close relationship with one another and raises the possibility that Worman crossed Whitman's path as a journalist. In 1886, Worman also entered the University of Pennsylvania's School of Law, where he was elected president of the legal fraternity ${ }^{11}$ and became the Philadelphia agent of Columbia Law School Times. ${ }^{12}$ Worman interviewed Whitman only months before graduating from Penn in 1888. A year later, he worked as a correspondent for the Philadelphia Press from Frenchtown, covering the presidential campaign of President Benjamin Harrison. In 1890, he returned to Camden ${ }^{13}$ to work in the office of Whitman's friend and eventual literary executor Thomas Harned. It is plausible, then, that Worman knew Harned, Whitman, or both at the time of the interview.

The interview is signed "Cessator," the pseudonym of the only Signal editor who used a Latin penname, Francis B. Lee. ${ }^{14}$ Lee joined Worman at Penn in the fall of $1888,{ }^{15}$ studying finance and journalism. While continuing to contribute to The Signal, Lee wrote for Penn's student newspaper, The Pennsylvanian. ${ }^{16}$ After 1890, Lee apparently heeded Whitman's advice not to write poetry because he abandoned poetry in The Signal and devoted his life to journalistic and historical writing. He wrote extensively for Trenton newspapers and published two massive histories of the city, which earned him "repute as a state historian of note, an important functionary of patriotic celebrations, a fluent speaker, and an all around popular citizen."17

"Cessator" is Latin for "one who loiters," and Lee's hybrid career matches his pseudonym - part classical lawyer and part loitering, loafing Whitmanite. While the academic rigor of the Model School undoubtedly stressed classical literature, Lee's commentary in the interview-his judgment of Whitman as "one of the sublimest" American poets, "in the true image of the Maker"indicates the stirrings of a radical literary sensibility, and his own poetic and journalistic submissions to The Signal, both before and after his graduation, often reflect an interest in experimentation. Although he used traditional meter and rhyme, Lee played with fonts and dialects and used innovative approaches to the line. The interview with Whitman seems to have confirmed his own rethinking of poetry as something rooted in experience rather than the classroom.

Lee's life was altered when Worman died in February 1890. The Signal printed an obituary, which Lee most likely wrote for his fellow interviewer, 
editor, and classmate: "the black-winged Angel of Death [came] after a brief illness from typhoid fever and resultant heart failure." Worman, "one of the most brilliant men who ever graduated from the Model School," lived a very brief but impressive life ${ }^{18}$ In addition to Lee's memoriam, we find a sorrowful tone in the final lines of his poem, "Stanzas," published soon after Worman's death: "Sweet love will die-he cannot live in that heart which knows only sorrow." 19 After his friend's death, Lee contributed only one more poem to The Signal before graduating from Penn and establishing himself as a Trenton lawyer and writer. While other young Whitmanites saw the poet as a prophet, Lee and Worman seemed to approach Whitman as a professional mentor.

The poet who once referred to his readers as pupils and eleves found himself in Camden giving advice directly to scholars from his adopted state. While Whitman's greatest works were written prior to his residence in Camden, he took advantage of his last location to influence and instruct the visitors who came to see him. If Whitman felt unresolved about the fate of his poetry, he was at least satisfied by the many visitors he received because of his poetry. Whitman's time in Camden allowed him to encounter many notable people from New Jersey and elsewhere- "I shall never be sorry I was left over in Camden!" said Whitman; "Washington, New Orleans, Brooklyn . . . are the cities of things begun - this is the city of things finished." ${ }^{20}$ Camden, however, was not a place where Whitman settled into slow decay; it was a place where he kept actively working on Leaves of Grass virtually to the day of his death. And it was a place, as this brief interview demonstrates, where he was able to do in person what his poetry sought to do in print: advise the new generations, the "poets to come,"

The College of New fersey

Nicole KuKawsKi

\section{NOTES}

1 The Signal (February 1888), 3-4. A bound copy of the first three years of The Signal (1885-1888) is available in The College of New Jersey's Roscoe L. West Library.

2 Horace Traubel, With Walt Whitman in Camden (Boston: Small, Maynard and Company, 1906), 70. Available online at The Walt Whitman Archive (www.whitmanarchive.org).

3 David S. Reynolds, Walt Whitman's America: A Cultural Biography (New York: Vintage, 1995), 34, 62.

4 Gary Schmidgall, ed. Intimate With Walt: Selections from Whitman's Conversations with Horace Traubel, 1888-1892 (Iowa City: University of Iowa Press, 2001), 52, 104.

5 Leaves of Grass, Comprehensive Reader's Edition, ed. Harold W. Blodgett and Sculley Bradley (New York: New York University Press, 1965), 391.

6 “A Backward Glance O'er Travel'd Roads," LG, 562.

7 Rachel Jarrold and Glenn Fromm, Time: The Great Teacher (Princeton: Princeton University Press, 1955), 19. 
8 Jarrold, 20.

9 “George Worman," The Signal (May 1887), 8.

10 "History of the Courier-Post," Courier-Post Online, www.gannett.com/map/ ataglance/cherryhi.htm.

11 The Signal (February 1888), 9.

12 The Signal (May 1888), 6.

13 Howe, Camden City Directory (1890). Camden County Historical Library.

14 The Signal (November 1888), 51.

15 The Signal (November 1888), 49.

16 The Signal (April 1889), 180.

17 "Lee Avenue," History of Trenton, trentonhistory.org/exp/journalism.htm.

18 "In Memoriam: George White Worman," The Signal (February 1890), 97; although this article is unsigned, Lee contributed signed memorials of Worman to other area newspapers.

19 The Signal (February 1890), 146.

20 Schmidgall, 44.

$21 L G, 14$.

\section{AN UNPUBLISHED EARLY 1870s PHOTOGRAPH OF WHITMAN}

The photograph appearing at the beginning of this issue of the Walt Whitman Quarterly Review and reproduced here is a previously unknown image. It is printed courtesy of Kendall Reed, who recently added the photograph to his collection. The photo is on a card stamped "Pendleton, 297 Fulton Street, Cor. of Johnson, Brooklyn." The New York City Directory lists Pendleton at this address starting in 1869, and advertisements for William S. Pendleton's studio at this address (as "a practical photographer" who directly imports "the best stereoscopic views," with "a large assortment of New York and Brooklyn views") appear in the Brooklyn Daily Eagle in 1870. In 1872, G. Frank Pearsall opened a studio next door to Pendleton's, at 298 Fulton. Whitman had several photos taken by

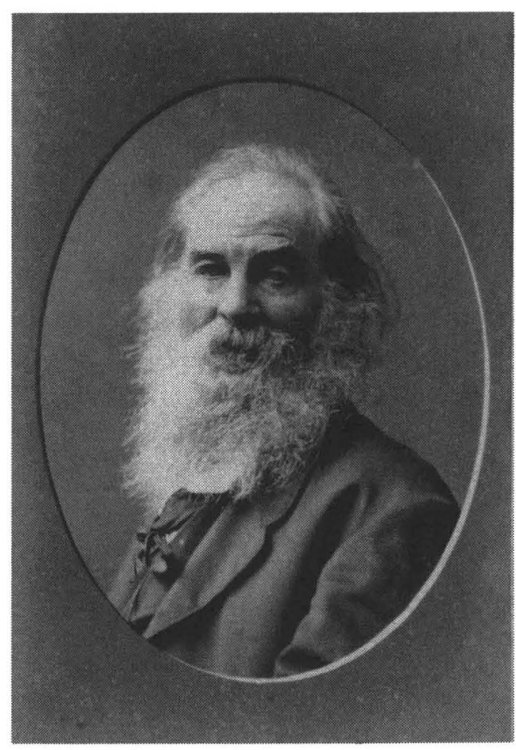

